Research paper

\title{
Development of a visible loop mediated isothermal amplification assay for rapid detection of Bacillus anthracis
}

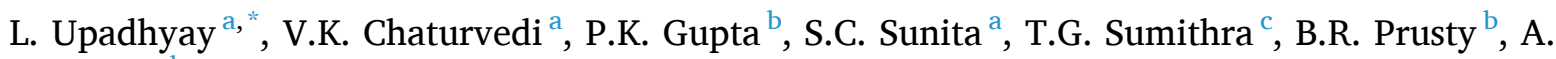 \\ K. Yadav ${ }^{\mathrm{d}}$ \\ ${ }^{a}$ Division of Biological Products, ICAR-Indian Veterinary Research Institute, Izatnagar, 243122, Uttar Pradesh, India \\ ${ }^{\mathrm{b}}$ Division of Biotechnology, ICAR-Indian Veterinary Research Institute, Izatnagar, 243122, Uttar Pradesh, India \\ ${ }^{\mathrm{c}}$ ICAR-Central Marine Fisheries Research Institute, Kochi, 682 018, India \\ d ICAR-National Research Centre on Pig, Rani, Guwahati, 781131, Assam, India
}

\section{A R T I C L E I N F O}

\section{Keywords:}

Bacillus anthracis

Pag gene

LAMP

\begin{abstract}
A B S T R A C T
Distressing effects on animal and human health with lethal progression, being used as bioweapon and shared features with non-pathogenic bacteria demands sensitive, specific, safe, cost effective and rapid detection methods for anthrax causing organisms. Conventional microbiology based diagnostics for anthrax are time consuming and need sophisticated equipment, while molecular diagnostics require less time and labor. The Loop mediated isothermal amplification assay (LAMP) is rapid, sensitive and specific assay and requires no specialized equipment. In the present study, we developed a LAMP assay for rapid as well as specific detection of Bacillus anthracis. The optimized assay produced positive results with the Sterne strain and one field isolate of $B$. anthracis and, negative results with other bacteria of the same and different genera within $2 \mathrm{~h}$. Sensitivity was 500 fg of total DNA of $B$. anthracis, which was 100 times more sensitive than conventional PCR. The present study also demonstrated that the simple method of total DNA extraction by repeated boiling and freezing will not adversely affect the LAMP results. In conclusion, the optimized LAMP assay is a promising tool for the specific, sensitive, less time-consuming diagnosis for anthrax causing bacteria and also, for detecting the virulence of suspected B. anthracis cultures.
\end{abstract}

\section{Introduction}

Anthrax usually caused by Bacillus anthracis is well known since antiquity for its serious devastating effect on animal as well as on human health [1]. Due to its dormant spores that can survive even the extreme environmental conditions, anthrax has also received much attention as a biological weapon [2]. The quick onset and rapid lethal progression in anthrax cases necessitate development of rapid, reliable, sensitive and specific methods for the detection of organisms causing anthrax. Conventional microbiological methods for this purpose require several days and are less sensitive [3]. Moreover, the numerous phenotypic and genotypic characteristics of $B$. anthracis were reported as common with other bacteria of the same and different genera especially with $B$. cereus group which are unable to produce anthrax [3-5]. Likewise, non-pathogenic isolates of $B$. anthracis lacking plasmid encoding anthrax toxin was reported [6,7]. Furthermore, $B$. cereus strains causing anthrax by the production of anthrax toxin were also isolated [8]. All these facts point out the need for an anthrax toxin based diagnostic methods for the specific identification of anthrax causing organisms.

Consequently, several nucleic acid-based assays targeting anthrax toxin genes have been optimized for the reliable, quick, specific and sensitive identification of organisms causing anthrax. However, these require expertise, expensive devices, heavy infrastructure laboratories and complicated protocols [9], thus are unsuitable for routine laboratories. The Loop-mediated isothermal amplification (LAMP) assay is preferred over other nucleic acid-based assays because it is fast, less labor-intensive and does not require any sophisticated equipment or skilled personnel, and is suitable for the applications at field level and routine laboratories [10]. Therefore, in the present study we have optimize anthrax toxin specific LAMP-PCR as a specific, sensitive, time and cost-effective method for the detection of anthrax causing bacteria.

\footnotetext{
* Corresponding author.

E-mail addresses: laxmi.upadhyay@hotmail.com (L. Upadhyay), vkchaturvedi@mail.com (V.K. Chaturvedi), praveen.indian@gmail.com (P.K. Gupta), sumithravet@gmail.com (T.G. Sumithra),dr.ajayyadav07@gmail.com (A.K. Yadav).
} 
Table 1

Different bacteria used in the study.

\begin{tabular}{|c|c|}
\hline Bacteria & Source \\
\hline $\begin{array}{l}\text { Bacillus anthracis } \\
\text { Sterne's strain }\end{array}$ & $\begin{array}{l}\text { Division of Biological Standardization, IVRI (Indian } \\
\text { veterinary Research Institute), Izatnagar }\end{array}$ \\
\hline B. anthracis IVRI strain & Division of Biological Standardization, IVRI, Izatnagar \\
\hline B. cereus MTCC 7409 & Microbial Type Culture Collection (MTCC), Chandigarh \\
\hline B. subtilis MTCC 1133 & MTCC, Chandigarh \\
\hline $\begin{array}{l}\text { B. megaterium MTCC } \\
1684\end{array}$ & MTCC, Chandigarh \\
\hline $\begin{array}{l}\text { Salmonella Typhimurium } \\
\quad \text { E2393 }\end{array}$ & National Salmonella Centre, IVRI, Izatnagar \\
\hline Brucella abortus strain 19 & Division of Biological Products, IVRI, Izatnagar \\
\hline $\begin{array}{l}\text { Pasteurella multocida } \\
\quad \text { strain P52 }\end{array}$ & Division of Biological Products, IVRI, Izatnagar \\
\hline Escherichia coli M15 & Division of Biological Products, IVRI, Izatnagar \\
\hline E. coli $\mathrm{DH} 5 \alpha$ & Division of Biological Products, IVRI, Izatnagar \\
\hline Clostridium perfringens & $\begin{array}{l}\text { Division of Veterinary Bacteriology and Mycology, IVRI, } \\
\text { Izatnagar }\end{array}$ \\
\hline Campylobacter jejuni & Division of Veterinary Public Health, IVRI, Izatnagar \\
\hline Arcobacter sp. & Division of Veterinary Public Health, IVRI, Izatnagar \\
\hline Leptospira sp. & $\begin{array}{l}\text { Division of Veterinary Bacteriology and Mycology, IVRI, } \\
\text { Izatnagar }\end{array}$ \\
\hline Mycoplasma capri & $\begin{array}{l}\text { Division of Veterinary Bacteriology and Mycology, IVRI, } \\
\text { Izatnagar }\end{array}$ \\
\hline Listeria monocytogenes & $\begin{array}{l}\text { Division of Veterinary Bacteriology and Mycology, IVRI, } \\
\text { Izatnagar }\end{array}$ \\
\hline Bordetella bronchiseptica & General Bacteriology Lab, CADRAD \\
\hline
\end{tabular}

\section{Materials and methods}

\subsection{Bacterial cultures}

Different bacteria used in the study are given in Table 1. Out of these, two strains of $B$. anthracis, virulent IVRI strain (originally attained from Bacteriological Laboratory, ICAR-Indian Veterinary Research Institute,
Mukteswar), another non-capsulated Sterne vaccine strain were obtained from Type Culture Laboratory, Division of Biological Standardization, ICAR-IVRI and used for the optimization of LAMP-PCR.

\subsection{Primer designing}

Based on the information gathered from GenBank and Blast database

Table 3

Optimized LAMP-PCR conditions.

\begin{tabular}{|c|c|c|c|}
\hline Components & $\begin{array}{l}\text { Concentration in } \\
\text { final reaction }\end{array}$ & Time & Temperature \\
\hline $\begin{array}{l}\text { 10X } \\
\text { Thermopol } \\
\text { buffer }\end{array}$ & $1 \mathrm{X}$ & \multirow[t]{6}{*}{$\begin{array}{l}90 \text { min } \\
\text { without } \\
\text { loop primer }\end{array}$} & \multirow{13}{*}{$\begin{array}{l}\text { Reaction temperature was } \\
64^{\circ} \mathrm{C} \text { and enzyme } \\
\text { inactivation was done at } \\
80^{\circ} \mathrm{C} \text { for } 5 \text { min }\end{array}$} \\
\hline $\begin{array}{l}\mathrm{dNTP}(10 \\
\mathrm{mM})\end{array}$ & $1.2 \mathrm{mM}$ & & \\
\hline $\begin{array}{l}\text { PAG-F3 (5 } \\
\text { pM) }\end{array}$ & $5 \mathrm{pM}$ & & \\
\hline $\begin{array}{l}\text { PAG-B3 (5 } \\
\text { pM) }\end{array}$ & $5 \mathrm{pM}$ & & \\
\hline $\begin{array}{l}\text { PAG-FIP (50 } \\
\text { pM) }\end{array}$ & $40 \mathrm{pM}$ & & \\
\hline $\begin{array}{l}\text { PAG-BIP (50 } \\
\text { pM) }\end{array}$ & $40 \mathrm{pM}$ & & \\
\hline $\begin{array}{l}\text { PAG-LoopF } \\
\quad(50 \mathrm{pM})\end{array}$ & $20 \mathrm{pM}$ & \multirow{7}{*}{$\begin{array}{l}60 \text { min with } \\
\text { loop } \\
\text { primers }\end{array}$} & \\
\hline $\begin{array}{l}\text { PAG-LoopR } \\
\quad(50 \mathrm{pM})\end{array}$ & $20 \mathrm{pM}$ & & \\
\hline Betaine & $1 \mathrm{M}$ & & \\
\hline $\mathrm{MgSO}_{4}$ & $6 \mathrm{mM}$ & & \\
\hline NFW & $\begin{array}{l}\text { To make up to } 23 \\
\mu l\end{array}$ & & \\
\hline Template & $1 \mu \mathrm{l}$ & & \\
\hline $\begin{array}{l}\text { Bst DNA } \\
\text { polymerase }\end{array}$ & $1 \mu \mathrm{l}$ & & \\
\hline
\end{tabular}

Table 2

Details of primers used in the study.

\begin{tabular}{ll}
\hline Primer Name & Sequence $\left(5-{ }^{\prime}-3^{\prime}\right)$ \\
\hline PAG-Full-Upper & GAAGTTAAACAGGAGAACCGGTTA \\
PAG-Full-Lower & TTATCCTATCTCATAGCCTTTTTAGAAA \\
PAG-F3 & AGGATCAATCCACACAGAATAC \\
PAG-B3 & GGTAACACGTTGTAGATTGGA \\
PAG-FIP(F1c + F2) & CTGCAGATACACTCCCACCAATGGACACATACTAGTGAAGTACA \\
PAG-BIP(B1c + B2) & ACGGTCGCAATTGATCATTCACCAGCGGTATTTAAACCCATTG \\
PAG-LoopF & GAACGACGCATGCACTTC \\
PAG-LoopR & GGGAAAGAACTTGGGCTGA \\
\hline
\end{tabular}

F1 ACtAGTGAAGTACATGgAAATGCAGAAGTGCATGCGTCGTTCTTTGATATTGGTGGGAGTGTATCTGCAGGATTT B1C AGtAATtCGAATtCAAGTACGgTCGCAATTGATCATTCACTATCTCTAGCAGGGGAAAGAACTtGgGGCTGAAACA B2C $\longrightarrow$ ATGGGTTTAAATACCGCTGATACAGCAAGATTAAATGCCAATATTAGATATGTAAATACTGGGACGGCTCCAATCT B3 ACAACGTGTTACC

Fig. 1. Schematic diagram on the position of different primers used in LAMP assay. 


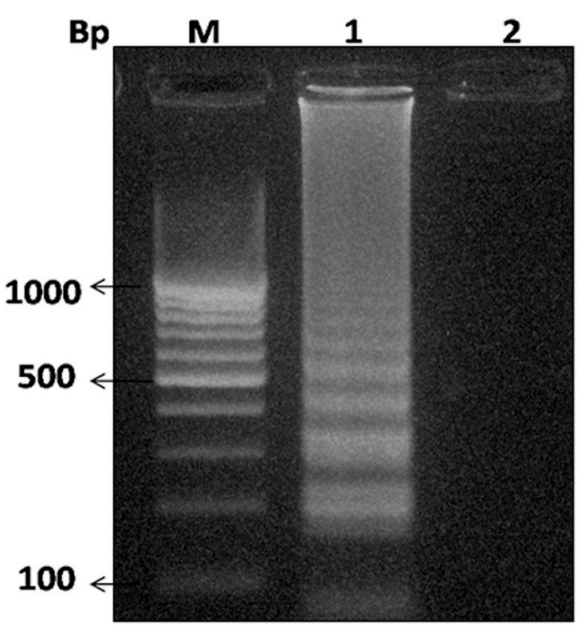

a

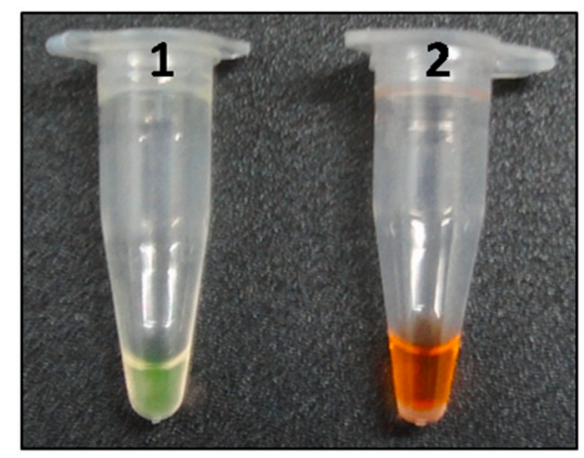

C

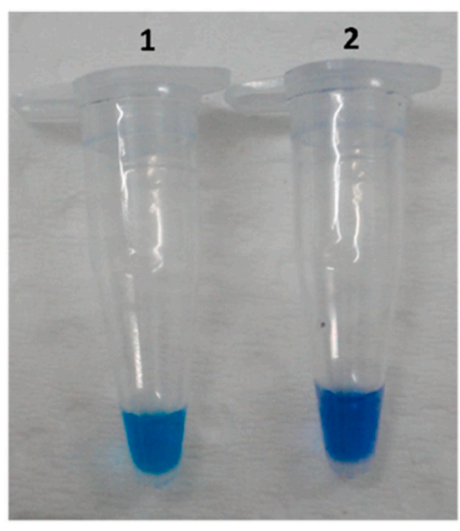

b

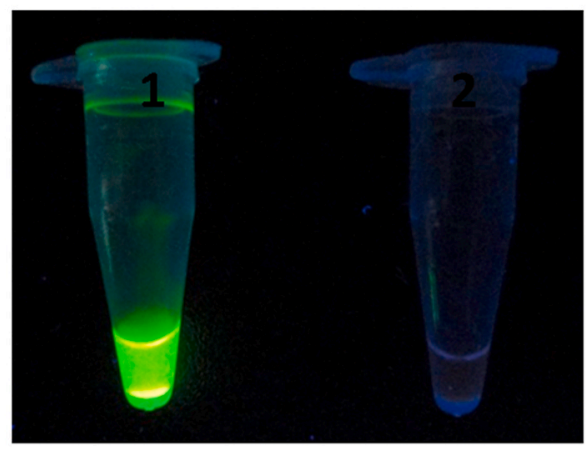

d

Fig. 2. Interpretation of LAMP-PCR results by (a) Agarose gel electrophoresis (b) HNB dye based detection under white light (c) SYBR Green I dye based detection under white light (d). SYBR Green I dye based detection under UV light: Lane M: 100 bp Ladder; Lane/Tube 1: Positive; Lane/Tube 2: Negative

of NCBI, LAMP primers specific for pag gene (Accession Number KJ631748) [encoding Protective Antigen (PA) portion of anthrax toxin] were designed using Primer Explorer V4 online software (http:// primerexplorer.jp/e) (Table 2; Fig. 1). The primers were custom synthesized by Integrated DNA Technologies (Coralville, Iowa).

\subsection{Total DNA extraction}

A simple method for total DNA extraction having the minimal risk for biohazard/laboratory acquired infection [11] was used in the present study. Simultaneously plasmid was isolated from $B$. anthracis Sterne strain using QIAGEN maxi kit (M/s Helden, Germany) with minor modifications as pag encoding PA is located on pXO1 plasmid.

\subsection{Conventional PCR}

Conventional PCR for pag gene was carried out as described earlier [12]. Briefly the reaction was perform in $0.2 \mathrm{~mL}$ tube, with 10XPfX buffer; $3.75 \mu \mathrm{l}$ (1.5X), $50 \mathrm{mM}$ MgSO4; $1 \mu \mathrm{l}(2 \mathrm{mM}), 10 \mathrm{mM}$ dNTP; $0.5 \mu \mathrm{l}$ $(200 \mu \mathrm{M})$, PAG Forward primer; $0.75 \mu \mathrm{l}(50 \mathrm{pmol})$, PAG Reverse primer; $0.75 \mu \mathrm{l}$ (50 pmol), PX01 plasmid; $1 \mu \mathrm{l}$, Platinum Pfx polymerase; $0.25 \mu \mathrm{l}$ and Nuclease free water up to $25 \mu \mathrm{l}$. The following cycling conditions were used: Initial denaturation of $94^{\circ} \mathrm{C}$ for 5 min followed by 30 cycles of denaturation at $94{ }^{\circ} \mathrm{C}$ for $1 \mathrm{~min}$, annealing at $55{ }^{\circ} \mathrm{C}$ for $1 \mathrm{~min}$, extension at $68^{\circ} \mathrm{C}$ for $2 \mathrm{~min}$ and a final extension at $68^{\circ} \mathrm{C}$ for $10 \mathrm{~min}$. The amplified products were confirmed for the expected size (1683 bp) in $1.0 \%$ agarose gel.

\section{5. $L A M P-P C R$}

LAMP-PCR was first carried out in $25 \mu \mathrm{l}$ reaction volume as previously described [13] and the reaction was terminated by incubating at $80{ }^{\circ} \mathrm{C}$ for $5 \mathrm{~min}$. Subsequently the reaction was optimized by varying reaction conditions and components such as temperature $\left(58^{\circ} \mathrm{C}-66^{\circ} \mathrm{C}\right)$, $\mathrm{MgSO}_{4}(2-8 \mathrm{mM})$, dNTP $(0.4-1.4 \mathrm{mM})$, betaine $(0.6-1.4 \mathrm{M})$ and reaction time (10-90 $\mathrm{min})$ for identifying optimized ladder pattern. A positive control (plasmid of $B$. anthracis) and a negative control (nuclease free water) were also included in every reaction. The final reaction mixture of the standardized LAMP PCR is tabulated in Table 3

\begin{tabular}{llll}
\hline Components & $\begin{array}{l}\text { Concentration or } \\
\text { volume }\end{array}$ & Time & Temperature \\
\hline $\begin{array}{l}\text { 10X } \\
\text { Thermopol }\end{array}$ & $2.5 \mu \mathrm{l}$ & $\begin{array}{l}90 \mathrm{~min} \\
\text { without loop } \\
\text { primer }\end{array}$ & $\begin{array}{l}\text { Reaction temperature was } \\
64{ }^{\circ} \mathrm{C} \text { and Enzyme } \\
\text { inactivation at } 80^{\circ} \mathrm{C} \text { for } 5 \\
\text { min. }\end{array}$ \\
dNTP $(10 \mathrm{mM})$ & $1.2 \mathrm{mM}$ & \\
F3 $(5 \mathrm{pM})$ & $5 \mathrm{pM}$ & \\
B3 $(5 \mathrm{pM})$ & $5 \mathrm{p} . \mathrm{m}$. & \\
FIP $(50 \mathrm{pM})$ & $40 \mathrm{pM}$ & \\
BIP $(50 \mathrm{pM})$ & $40 \mathrm{pM}$ & & \\
LF $(50 \mathrm{pM})$ & $20 \mathrm{pM}$ & & \\
& & &
\end{tabular}



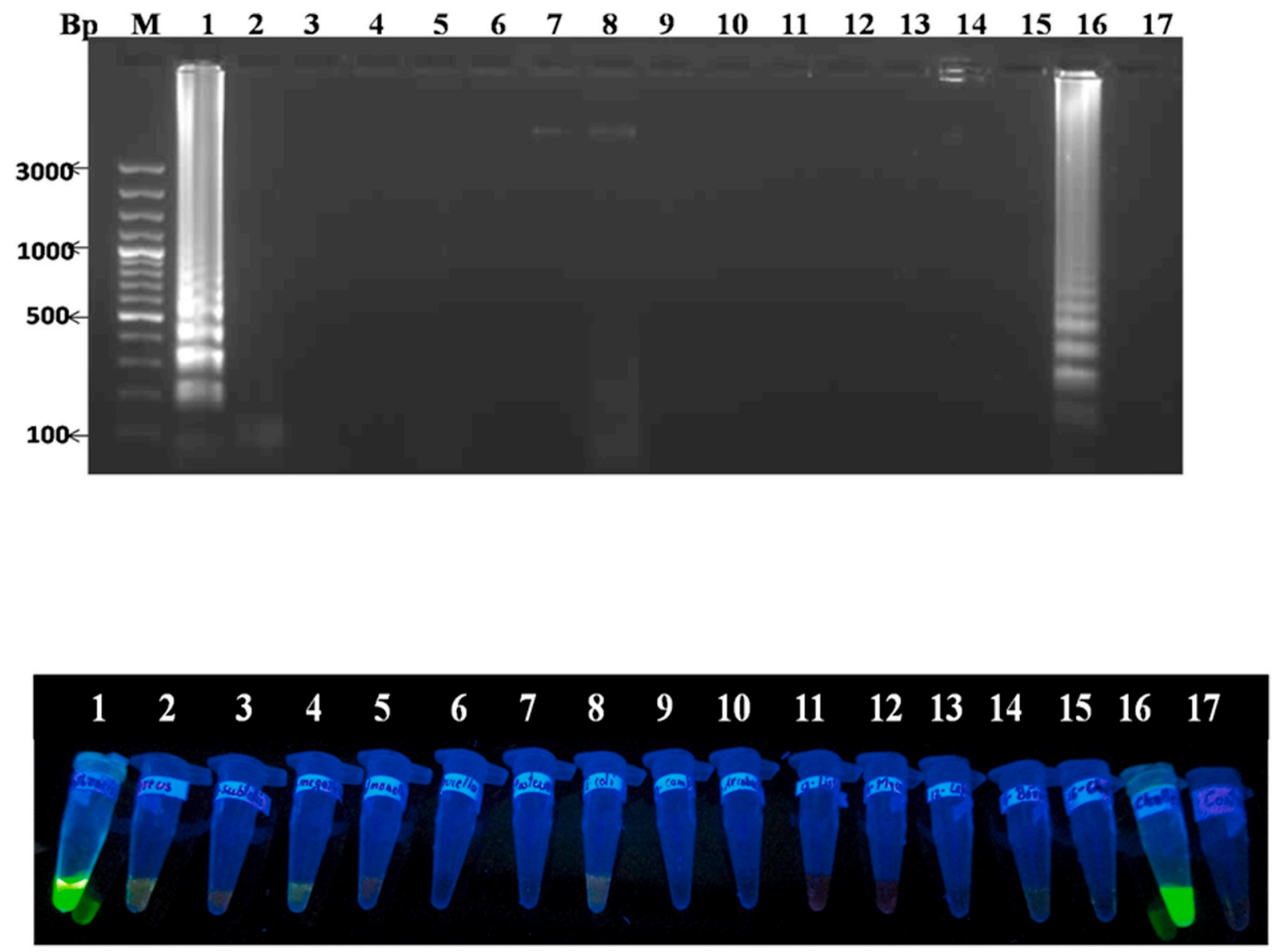

Fig. 3. Specificity evaluation of LAMP-PCR by agarose gel electrophoresis and SYBR Green I dye based detection under UV light: Lane M: GeneRulerTM100 bp Plus DNA Ladder; Lane/Tube 1: B. anthracis Sterne 34F2; Lane/Tube 2: B. cereus; Lane/Tube 3: B. subtilis; Lane/Tube 4: B. megaterium; Lane/Tube 5: Salmonella Typhimurium; Lane/Tube 6: Brucella abortus strain 19; Lane/Tube 7: Pasteurella multocida B:2; Lane/Tube 8: E. coli; Lane/Tube 9: Campylobacter jejuni; Lane/Tube 10: Arcobacter sp.; Lane/Tube 11: Leptospira sp.; Lane/Tube 12: Mycoplasma sp.; Lane/Tube 13: Listeria monocytogenes; Lane/Tube 14: Bordetella bronchoseptica; Lane/Tube 15: Clostridium perfringens; Lane/Tube 16: B. anthracis IVRI strain; Lane/Tube 17: Negative control

(continued)

\begin{tabular}{llll}
\hline Components & $\begin{array}{l}\text { Concentration or } \\
\text { volume }\end{array}$ & Time & Temperature \\
\hline LR $(50 \mathrm{pM})$ & $20 \mathrm{pM}$ & 60 min with & \\
Betaine & $1 \mathrm{M}$ & loop primers & \\
$\mathrm{MgSO}_{4}$ & $6 \mathrm{mM}$ & \\
$\mathrm{NFW}$ & To make up to & \\
& $23 \mu \mathrm{l}$ & \\
Template & $1 \mu \mathrm{l}$ & \\
Bst DNA & $1 \mu \mathrm{l}$ & \\
polymerase & & \\
\hline
\end{tabular}

\subsection{Detection of amplified LAMP products}

The amplified LAMP products were analyzed by naked eye as well as by agarose gel electrophoresis. The color difference between the positive and negative reactions after adding either $0.12 \mathrm{mM}$ hydroxynaphthol blue (HNB) dye (M/s Sigma Aldrich, USA) pre-amplification, or $1 \mu \mathrm{l}$ of 1000X SYBR Green I (M/s Invitrogen, USA) post-amplification was also then checked. For the confirmation of a successful assay, the products were then run on $2 \% \mathrm{w} / \mathrm{v}$ agarose in Tris-acetate-EDTA buffer containing $0.5 \mu \mathrm{g} / \mathrm{mL}$ ethidium bromide and checked under ultraviolet illumination.

\subsection{Detection of specificity and sensitivity}

Specificity was checked by employing the total DNA extracted from various bacteria as template (Table 1). Sensitivity was determined by limiting dilution method and compared with conventional PCR. Briefly, serial tenfold dilutions of total DNA from $B$. anthracis was prepared and $2 \mu \mathrm{l}$ from each dilution was used as template for LAMP-PCR and conventional PCR. The highest dilution producing distinct positive reaction was found out. DNA quantification of the undiluted supernatant was performed using Nanodrop ${ }^{\circledR}$ (Thermo Scientific, USA).

\section{Results and discussion}

The present paper describes the optimization of a LAMP-PCR for the specific and sensitive identification of anthrax causing bacteria in a user friendly platform. The main targets for diagnosis of anthrax are plasmidlocated virulence genes [14] which are considered as hallmark genetic feature of $B$. anthracis [15]. There are 2 virulent plasmids as pXO1 encoding 'toxin' [16] and pXO2 encoding 'capsule' [15]. However, pXO1 encoding anthrax toxin will be a more apt target, as the loss of pXO1 in environmental samples is infrequent while the loss of pXO2 is common [17]. Furthermore, The Sterne strain which lacks pXO2 has some virulence for humans [18] and certain animal species [19]. At the same time, $B$. anthracis lacking pXO1 is reported to be non-pathogenic [6]. Besides, some $B$. cereus strains causing anthrax through anthrax toxin were isolated [8], showing the need for pXO1 based assays. 

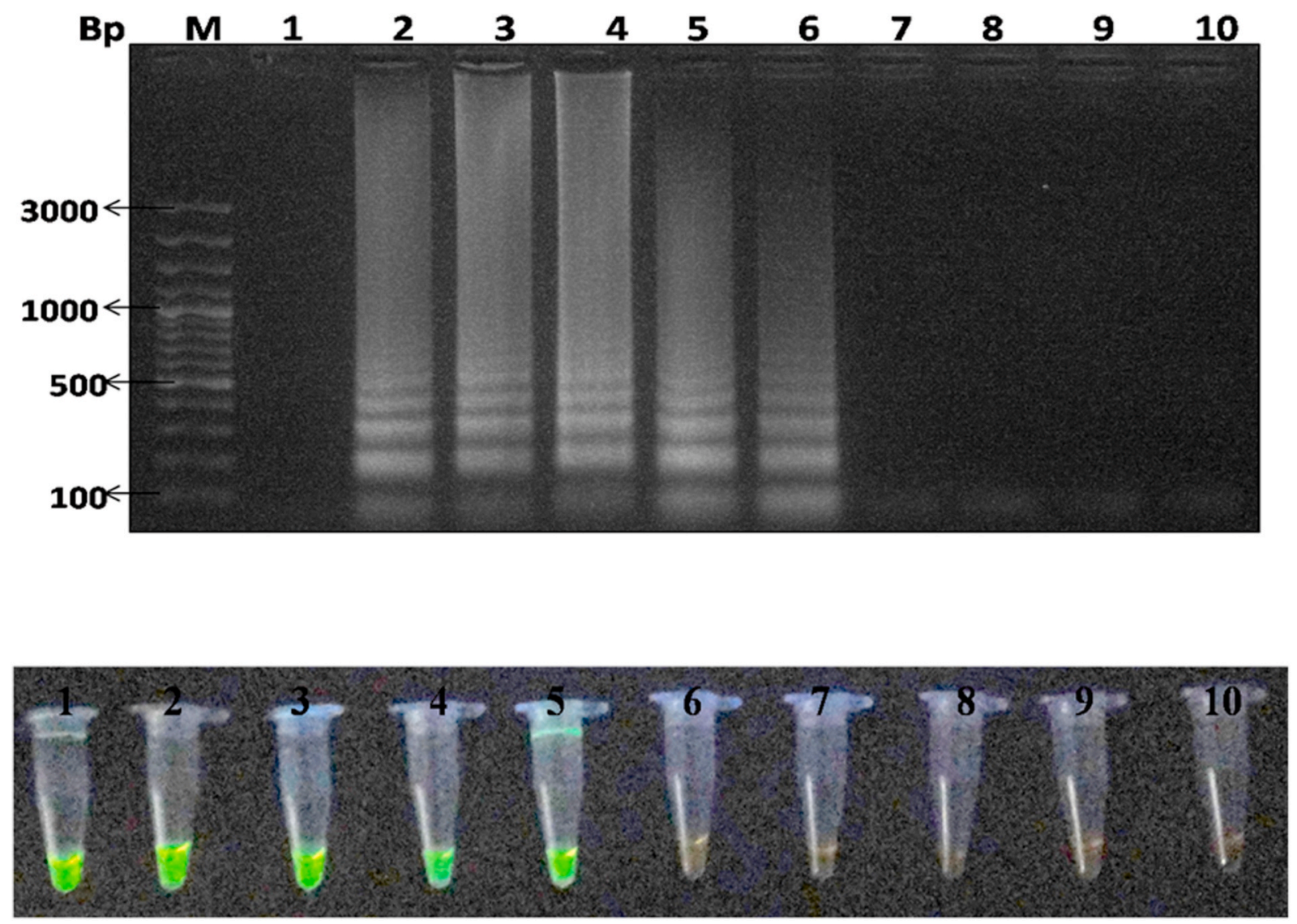

Fig: 4. Sensitivity evaluation of LAMP-PCR without loop primers by agarose gel electrophoresis and SYBR Green I dye based detection under UV light: Lane M: GeneRuler ${ }^{\mathrm{TM}} 100$ bp plus DNA ladder; Lane 1: Negative control; Lane 2/Tube 1: $500 \mathrm{ng} / \mu \mathrm{l}$; Lane 3/Tube 2: $50 \mathrm{ng} / \mu \mathrm{l}$; Lane 4/Tube 3: $5 \mathrm{ng} / \mu \mathrm{l}$; Lane 5/Tube 4: 500

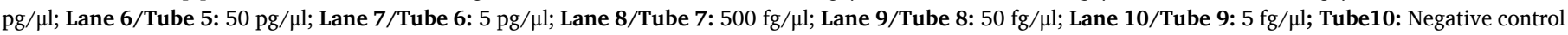

Accordingly, for identifying all bacteria that can produce anthrax together with the Sterne strain, pag encoding protective antigen (PA), the most essential component of anthrax toxin in pathogenesis was chosen as the target. As the virulence of all bacteria causing anthrax is mainly due to their toxin [20], detection methods aiming at pag have extra benefit for finding out the virulence of suspected organisms.

In LAMP-PCR reactions four primers recognizing six distinct regions of the target has extremely high specificity [21] and inclusion of two loop primers in the reaction mixture accelerate the amplification reaction [22]. Consequently, six LAMP primers including two loop primers were designed using Primer Explorer V4 online software, to recognize six specific regions on the highly conserved sequences of pag gene (302 bp to 614 bp) of B. anthracis (GenBank Accession number JQ798178).

As temperature is a critical factor for any successful LAMP reaction, the optimization assay was done at different temperatures starting from $58{ }^{\circ} \mathrm{C}$ to $66^{\circ} \mathrm{C}$. Although amplification happened at all these temperatures, the typical ladder like pattern with good intensity was seen at $64^{\circ} \mathrm{C}$. Further, optimization of different concentration of dNTPs, $\mathrm{MgSO}_{4}$ and betaine was carried out and the best amplification was found with $1.2 \mathrm{mM}, 6 \mathrm{mM}$ and $1 \mathrm{M}$, respectively. Similarly, optimal reaction time was determined by analyzing the LAMP products after different periods of incubation. Although the amplified products could be detected after $45 \mathrm{~min}$; the maximum amplification was observed after $60 \mathrm{~min}$. In order to investigate the differences in reaction time in the presence orabsence of loop primers, the optimal reaction time without loop primers was determined. In the absence of loop primers the amplified products could be detected after $60 \mathrm{~min}$ and the maximum amplification was observed after $90 \mathrm{~min}$. Thus, the results showed that inclusion of loop primers greatly reduced the reaction time from $90 \mathrm{~min}$ to $60 \mathrm{~min}$ as already reported [23]. Briefly, the optimized assay conditions were: 5 pmol of F3 and B3, 40 pmol of FIP and BIP, 20 pmol of LF and LR, 1.0 M betaine, 6 $\mathrm{mM} \mathrm{MgSO}_{4}, 1.2 \mathrm{mM}$ of dNTPs mix, 8U Bst DNA polymerase, $2.5 \mu \mathrm{l}$ of 10X ThermoPol reaction buffer and $1 \mu \mathrm{l}$ of target DNA in $25 \mu \mathrm{l}$ reaction volume. The assay was carried out at $64^{\circ} \mathrm{C}$ for $60 \mathrm{~min}$ and $90 \mathrm{~min}$ with loop primers and without loop primers respectively, followed by termination at $80{ }^{\circ} \mathrm{C}$ for $5 \mathrm{~min}$.

The interpretation of positive and negative results was done by four different methods. In the first method simple visual observation for the presence of turbidity was carried out as accumulation of reaction byproduct magnesium pyrophosphate in positive LAMP reactions can produce turbidity [21]. However, detection of turbidity requires some skill to distinguish between positive and negative LAMP results, so that other methods were also tried. In the second method LAMP product was run on $2 \%$ agarose gel which revealed a clear ladder like pattern (Fig. 2a) due to the formation of large stem loop cauliflower like structures [12] while no amplification and laddering pattern was observed with the negative control. However, in order to analyze this optimized LAMP assay without any specialized equipment and expertise, visual detection by addition of either SYBR Green I [10] or HNB dye [24] were also tried. With HNB dye, the purple color of the reaction mixture transformed to sky blue post-amplification in positive test (Fig. 2b) which could be detected by naked eye which is in accordance with the findings of Goto et al., 2018 (28) with the use of HNB dye. With SYBR Green I, the amplified products in positive assay gave green color while negative reaction developed orange color (Fig. 2c) and, under UV illumination at $475 \mathrm{~nm}$ positive LAMP reaction gave bright green fluorescence (Fig. 2d). Therefore, both dyes helped in the identification of positive LAMP reactions. However, HNB was more sensitive than SYBR green $I$ for distinguishing the positive and negative reactions. Additionally, since HNB was incorporated into the reaction mixture prior to 

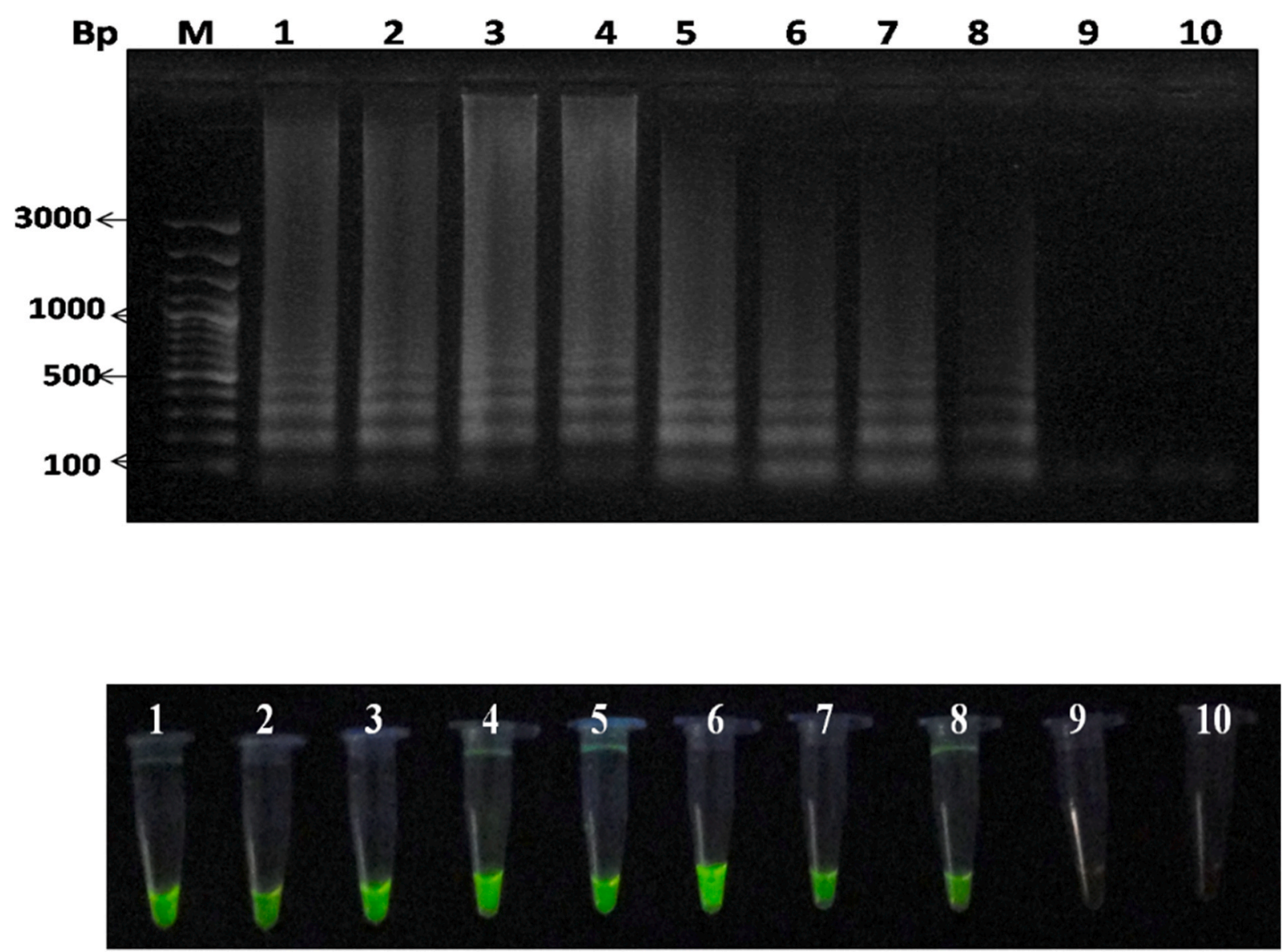

Fig: 5. Sensitivity evaluation of LAMP-PCR with loop primers by agarose gel electrophoresis and SYBR Green I dye based detection under UV light: Lane M:

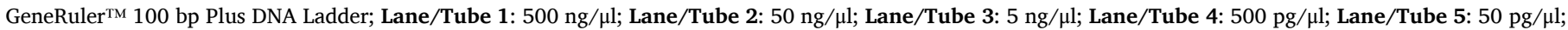

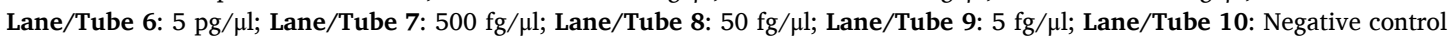

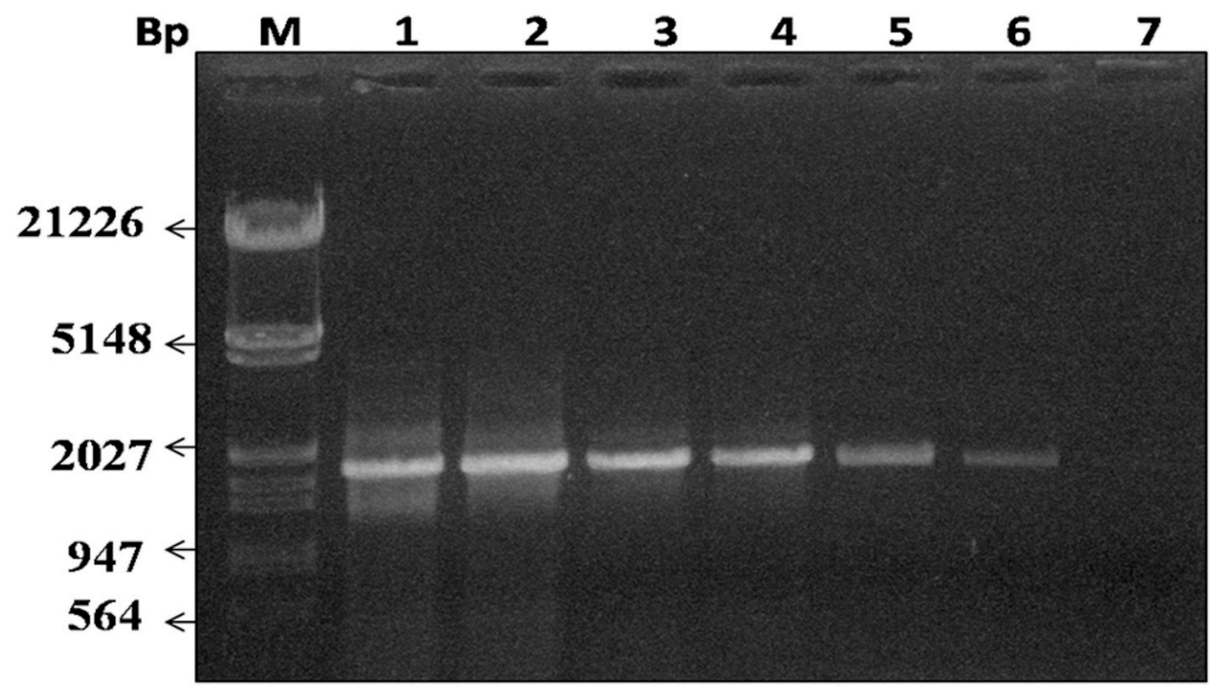

Fig: 6. Sensitivity evaluation of conventional PCR: Lane M: $\lambda$ DNA/EcoRI + HindIII digested; Lane 1: $500 \mathrm{ng} / \mu$ l; Lane 2: $50 \mathrm{ng} / \mu \mathrm{l}$; Lane 3: $5 \mathrm{ng} / \mu \mathrm{l}$; Lane 4: $500 \mathrm{pg} /$

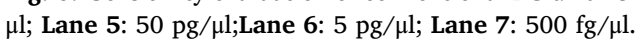

amplification, it eliminated the possibility of laboratory contamination caused by the opening of tubes post-amplification. The optimized LAMPPCR (both with and without loop primers) successfully produced positive reaction from both isolates of $B$. anthracis.

We used a simple method for the total DNA extraction from B. anthracis [11] and used as template in the optimized LAMP-PCR in addition to the plasmid isolated by commercial kit. As there is no chance of exposure to the active culture during this method of DNA extraction, excluding during initial inoculation of suspected sample, this method will contribute significantly in reducing the risk of laboratory acquired infection during the identification of suspected cultures. The present study demonstrated that this simple method of DNA extraction did not 
adversely affect the optimized LAMP-PCR assay results.

The optimized LAMP-PCR was found to be specific for anthrax causing bacteria as there was no false positive reaction with any other tested bacteria (Five Bacillus spp. and 12 non-Bacillus bacteria) (Fig. 3). At this point, it is important to note that some $B$. cereus strains carrying pXO1 and pXO2 plasmids and can produce anthrax like disease $[8,25]$ which cannot be differentiated from anthrax caused by $B$. anthracis by the present LAMP-PCR. However, recently it was revealed [26] that chromosomes of $B$. anthracis and the other $B$. cereus causing anthrax-like disease are genetically similar and there is no sub-group within $B$. cereus group which are genetically predisposed to anthrax pathogenesis, instead, any member of $B$. cereus may produce anthrax if they acquire the virulence plasmids. Thus clinically it is not important to differentiate such $B$. cereus strains capable of causing anthrax from toxigenic B. anthracis during anthrax diagnosis. Thus, the optimized LAMP-PCR can specifically detect all organisms that are capable of producing anthrax.

Sensitivity of the assay was 50 pg of total DNA without loop primers (Fig. 4) and 500 fg of total DNA with loop primers (Fig. 5) per reaction. Sensitivity of conventional PCR was 50 pg of total DNA (Fig. 6). Moser et al. [27] estimated that $1 \mathrm{pg}$ of total DNA of $B$. anthracis contained about 100 copies of pagA targets. Therefore, sensitivity of the optimized assay when translated into a copy number limit of detection, can be expressed as 5000 copies of anthrax toxin-specific plasmids for conventional PCR and LAMP assay without loop primers. In the similar manner, sensitivity of the optimized LAMP assay with loop primers was calculated as 50 copies of anthrax toxin-specific plasmids. Therefore, sensitivity of the optimized LAMP assay with loop primers was 100 times more than the conventional PCR. The results also showed that use of loop primers increased the sensitivity and reduced the reaction time of LAMP-PCR without altering the specificity as previously described [22].

In conclusion, the present paper reports optimization of a sensitive LAMP-PCR based assay for specific identification of cultures of bacteria that can cause anthrax. The assay can also be used for determining the virulence of suspected cultures. The assay was about 100 times more sensitive than the conventional PCR. Thus, this can be a promising alternative diagnostic tool for the specific, sensitive, time and costeffective and easy to perform identification method for anthrax causing bacteria.

\section{Acknowledgement}

The authors acknowledge the Director ICAR-IVRI for providing necessary facilities to carry out the experiment. LU is thankful to Indian Council of Agricultural Research for Junior Research Fellowship grant. The authors declare no conflict of interest.

\section{References}

[1] Ghosh N, Tomar I, Lukka H, Goel AK. Serodiagnosis of human cutaneous anthrax in India using an indirect anti-lethal factor IgG enzyme-linked immunosorbent assay. Clin Vaccine Immunol 2013;20:282-6.

[2] Wang DB, Tian B, Zhang ZP, Deng JY, Cui ZQ, Yang RF, Zhang XE. Rapid detection of Bacillus anthracis spores using a super-paramagnetic lateral-flow immunological detection system. Biosens Bioelectron 2013;42:661-7.
[3] Irenge LM, Gala JL. Rapid detection methods for Bacillus anthracis in environmental samples: a review. Appl Microbiol Biotechnol 2012;93:1411-22.

[4] Klichko VI, Miller J, Wu A, Popov SG, Alibek K. Anaerobic induction of Bacillus anthracis hemolytic activity. Biochem Biophys Res Commun 2003;303:855-62.

[5] Klee SR, Nattermann H, Becker S, Urban-Schriefer M, Franz T, Jacob D, Appel B. Evaluation of different methods to discriminate Bacillus anthracis from other bacteria of the Bacillus cereus group. J Appl Microbiol 2006;100:673-81.

[6] Turnbull PC, Hutson RA, Ward MJ, Jones MN, Quinn CP, Finnie NJ, Duggleby CJ, Kramer JM, Melling J. Bacillus anthracis but not always anthrax. J Appl Bacteriol 1992;72:21-8.

[7] Beyer W, Turnbull PC. Anthrax in animals. Mol Aspect Med 2009;30:481-9.

[8] Hoffmaster AR, Ravel J, Rasko DA, Chapman GD, Chute MD, Marston CK, De BK, Sacchi CT, Fitzgerald C, Mayer LW, Maiden MCJ, Priest FG, Barker M, Jiang L, Cer RZ, Rilstone J, Peterson SN, Weyant RS, Galloway DR, Read TD, Popovic T. Identification of anthrax toxin genes in a Bacillus cereus associated with an illness resembling inhalation anthrax. Proc Natl Acad Sci Unit States Am 2004;101: 8449-54.

[9] Aminu OR, Lembo T, Zadoks RN, Biek R, Lewis S, Kiwelu I, Mmbaga BT, Mshanga D, Shirima G, Denwood M, Forde TL. Practical and effective diagnosis of animal anthrax in endemic low-resource settings. bioRxiv 2020;3(24):004382. https://doi.org/10.1101/2020.03.24.004382.

[10] Parida M, Sannarangaiah S, Dash PK, Rao PVL, Morita K. Loop mediated isothermal amplification (LAMP): a new generation of innovative gene amplification technique; perspectives in clinical diagnosis of infectious diseases. Rev Med Virol 2008;18:407-21.

[11] Sumithra TG, Chaturvedi VK, Gupta PK, Sunita SC, Siju SJ, Susan C, Vergis J. Multiplex polymerase chain reaction assay for the specific detection of the organism causing anthrax. Proc Natl Acad Sci India B Biol Sci 2015;85:263-9.

[12] Sumithra TG, Chaturvedi VK, Gupta PK, Rai AK, Sunitha SC, Laxmi U. Development of Bacillus anthracis mutant with dominant negative inhibitory phenotype of protective antigen as a probable therapeutic potential against anthrax. J Vet Publ Health 2014;12:13-8.

[13] Notomi T, Okayama H, Masubuchi H, Yonekawa T, Watanabe K, Amino N, Hase T. Loop-mediated isothermal amplification of DNA. Nucleic Acids Res 2000;28:e63.

[14] Pannucci J, Okinaka RT, Sabin R, Kuske CR. Bacillus anthracis pXO1 plasmid sequence conservation among closely related bacterial species. J Bacteriol 2002; 184:134-41.

[15] Uchida I, Sekizaki T, Hashimoto K, Terakado N. Association of the encapsulation of Bacillus anthracis with a 60 megadalton plasmid. J Gen Microbiol 1985;131:363-7.

[16] Mikesell P, Ivins BE, Ristroph JD, Dreier TM. Evidence for plasmid-mediated toxin production in Bacillus anthracis. Infect Immun 1983;39:371-6.

[17] Mock M, Fouet A. Anthrax. Annu Rev Microbiol 2001;55:647-71.

[18] Wang JY, Roehrl MH. Anthrax vaccine design: strategies to achieve comprehensive protection against spore, Bacillus, and toxin. Med Immunol 2005;4:1-8.

[19] Cartwright ME, McChesney AE, Jones RL. Vaccination related anthrax in three llamas. J Am Vet Med Assoc 1987;191:715-6.

[20] Cella LN, Sanchez P, Zhong W, Myung NV, Chen W, Mulchandani A. Nano aptasensor for protective antigen toxin of anthrax. Anal Chem 2010;82:2042-7.

[21] Mori Y, Nagamine K, Tomita N, Notomi T. Detection of loop- mediated isothermal amplification reaction by turbidity derived from magnesium pyrophosphate formation. Biochem Biophys Res Commun 2001;289:150-4.

[22] Nagamine K, Hase T, Notomi T. Accelerated reaction by loop-mediated isothermal amplification using loop primers. Mol Cell Probes 2002;16:223-9.

[23] Nagamine K, Hase T, Notomi T. Loop-mediated isothermal amplification reaction using a nondenatured template. Clin Chem 2001;47:1742-3.

[24] Goto M, Honda E, Ogura A, Nomoto A, Hanaki KI. Colorimetric detection of loopmediated isothermal amplification reaction by using hydroxy naphthol blue. Biotechniques 2009;46(3):167-72.

[25] Klee SR, Brzuszkiewicz EB, Nattermann H, Brüggemann H, Dupke S, Wollherr A, Franz T, Pauli G, Appel B, Liebl W, Couacy-Hymann E, Boesch C, Meyer FD, Leendertz FH, Ellerbrok H, Gottschalk G, Grunow R, Liesegang $\mathrm{H}$. The genome of a Bacillus isolate causing anthrax in chimpanzees combines chromosomal properties of $B$. cereus with B. anthracis virulence plasmids. PloS One 2010;5:e10986.

[26] Zwick ME, Joseph SJ, Didelot X, Chen PE, Bishop-Lilly KA, Stewart AC, Willner K, Nolan N, Lentz S, Thomason MK, Sozhamannan S. Genomic characterization of the Bacillus cereus sensulato species: backdrop to the evolution of Bacillus anthracis. Genome Res 2012;22:1512-24.

[27] Moser MJ, Christensen DR, Norwood D, Prudent JR. Multiplexed detection of anthrax-related toxin genes. J Mol Diagn 2006;8(1):89-96. 